\title{
STRATEGI PENINGKATAN BRAND LOYALTY DAN CUSTOMER SATISFACTION BISNIS YOGURT DI INDONESIA (STUDI KASUS: PT YUMMY FOOD UTAMA)
}

\author{
Indana Saramita Rachman*)1, Aida Vitayala S Hubeis ${ }^{* *}$, dan Suryani Sidik F Motik ${ }^{* * *}$ \\ *) PT. Indoprima Advisa Management \\ Jalan Salatiga No.3, Menteng, Jakarta Pusat 10340 \\ **) Departemen Sains Komunikasi dan Pengembangan Masyarakat, Fakultas Ekologi Manusia, Institut Pertanian Bogor \\ Jl. Kamper, Wing 1, Level 5, Kampus IPB Darmaga Bogor 16680 \\ ${ }^{* * *}$ The School of Business and Management, Institut Teknologi Bandung \\ Kampus Jakarta, Graha Irama 12th Floor, Jl. HR Rasuna Said Kav. 1-2, Jakarta 12950
}

\begin{abstract}
The objectives of this study were to analyze the key success factors of the yogurt business and recommend strategies to increase brand loyalty and customer satisfaction at PT Yummy Food Utama. The method used in this research was descriptive analysis method with case study approach at PT Yummy Food Utama with descriptive analysis, PESTEL framework, and Porter's five forces. The result of descriptive analysis shows that the key success factors of yogurt business at PT Yummy Food Utama in terms of the behavior of the importance of consuming yogurt, accessibility products, and acceptability of the products are understanding the benefits of consuming yogurt, brand loyalty and product quality while the result of PESTEL framework and Porter's five forces shows the strategies that has to be done by PT Yummy Food Utama on brand loyalty and customer satisfaction are retaining and maintaining the quality of products, educating the public and delivering the benefits of the importance of consuming yogurt, increasing the popularity of the product through the promotion by using electronic media (television advertising), establishing communication with consumers, opening up a free hotline "24 hours 7 days" and reproducing the flavors of products.
\end{abstract}

Keywords: yoghurt, key success factor, brand loyalty, customer satisfaction, PESTEL framework, Porter's Five Forces

\begin{abstract}
ABSTRAK
Penelitian in bertujuan menganalisis faktor kunci keberhasilan dari bisnis yogurt dan merumuskan strategi untuk meningkatkan brand loyalty dan customer satisfaction pada PT Yummy Food Utama. Metode yang digunakan dalam penelitian ini adalah deskriptif kualitatif dalam bentuk studi kasus pada PT Yummy Food Utama dengan menggunakan analisis deskriptif, kerangka PESTEL dan Porter's five forces. Hasil analisis deskriptif menunjukkan faktor-faktor kunci keberhasilan bisnis yogurt PT Yummy Food Utama ditinjau dari perilaku pentingnya mengkonsumsi yogurt, aksessibilitas produk dan akseptabilitas produk adalah pemahaman manfaat mengkonsumsi yogurt, brand loyalty dan kualitas produk. Sedangkan dari hasil analisis PESTEL dan Porter's Five Forces menunjukkan strategi yang harus dilakukan oleh PT Yummy Food Utama dalam meningkatkan brand loyalty dan customer satisfaction antara lain: mempertahankan dan menjaga kualitas produk, mengedukasi masyarakat dan menyampaikan manfaat akan pentingnya mengkonsumsi yogurt, meningkatkan popularitas produk melalui media promosi elektronik (iklan di televisi), membangun komunikasi dengan konsumen, membuka hotline gratis "24 jam 7 hari" dan memperbanyak varian rasa produk.
\end{abstract}

Kata kunci: yogurt, faktor kunci keberhasilan, brand loyalty, customer satisfaction, PESTEL, Porter's five forces.

${ }^{1}$ Alamat Korespondensi:

Email: indanasaramita@gmail.com 


\section{PENDAHULUAN}

Perkembangan dunia bisnis saat ini semakin pesat khususnya perkembangan industri yang semakin tinggi dan kompleks yang dibuktikan dengan banyaknya pertumbuhan industri-industri baru. Pertumbuhan ini mengakibatkan adanya persaingan antar industri yang sejenis. Suatu industri dapat tetap bertahan jika mempunyai strategi dan kebijakan untuk memeroleh keunggulan yang kompetitif. Selain itu, suatu industri juga diharapkan untuk mampu memberikan performa yang terbaik untuk pelanggan. Hal ini diakibatkan oleh kebutuhan pelanggan yang semakin kritis dalam memilih satu jenis produk.

Salah satu jenis industri yang mempunyai peluang yang cukup baik adalah industri pengolahan susu. Dalam industri ini, ilmu pengetahuan dan teknologi sangat berkembang pesat. Pengembangan inovasiinovasi produk dibutuhkan seiring dengan kebutuhan konsumen akan jenis makanan dan minumam yang sehat berkualitas sehingga memberikan banyak peluang untuk mengembangkannya, khususnya terhadap peningkatan jumlah konsumsi susu di Indonesia. Namun demikian, ternyata kebutuhan susu di Indonesia belum dapat diimbangi dengan kemampuan peternak sapi nasional untuk menyediakan produk susu yang berkualitas (Sanny, 2011). Dari sisi manfaat, susu memiliki manfaat yang sangat besar, terutama bagi anak-anak. Dari sisi permintaan, konsumsi susu nasional per tahun telah mencapai $7 \%$, yaitu 3 juta ton per tahun (Tuthan, 2014).

Peluang industri pengolahan susu di Indonesia sangat baik, mengingat Indonesia dengan jumlah penduduk mencapai 237 juta jiwa (BPS, 2010). Pertumbuhan sektor industri pengolahan susu diketahui pada tahun 2013 sebesar $12 \%$ atau meningkat dibandingkan pada tahun sebelumnya sebesar 10\% (Susanto, 2015). Herawati dan Priyanto (2013) menyatakan untuk mendukung industri pengolahan susu, dibutuhkan peran dari lembaga terkait seperti Dewan Persusuan Nasional (DPN) dan Gabungan Koperasi Susu Indonesia (GKSI) untuk mendorong terciptanya iklim yang kondusif bagi usaha peternakan sapi perah, meningkatkan akses pelaku usaha agribisnis persusuan terhadap berbagai sumberdaya, dan melakukan negosiasi harga hasil produksi dan bantuan koordinasi teknis lainnya. Menurut Sanny (2011) industri pengolahan susu di Indonesia diprediksi akan tumbuh sebesar $10 \%$ per tahun, seiring dengan tumbuhnya industri makanan dan minuman yang menggunakan susu sebagai bahan bakunya. Selain itu, dengan meningkatnya kesadaran masyarakat akan pentingnya manfaat susu untuk kesehatan, merupakan peluang bagi perusahan susu olahan untuk menciptakan varian-varian baru produk susu olahan.

Industri pengolahan susu di Indonesia mempunyai peranan penting dan strategis dalam upaya penyediaan dan pencukupan gizi masyarakat (Depperin, 2009). Menurut Herawati dan Priyanto (2013) terdapat 48 industri pengolahan susu di Indonesia. Industri pengolahan susu khususnya yogurt dan susu asam saat ini mengalami pertumbuhan sebesar $15 \%$ dan mencapai penjualan sebesar Rp5.61 miliar pada tahun 2010 sampai tahun 2015 (Euromonitor International, 2015). PT Yummy Food Utama (PT Yummy) merupakan salah satu industri pengolahan susu terbesar di DKI Jakarta dengan jenis produk yogurt yang merupakan produk terbaiknya saat ini. Sudirman (2009), menyatakan bahwa Yummy memiliki sejarah perkembangan dan peningkatan penjualan produk yang tajam sebesar 73\% pada tahun 2008 dibandingkan pada tahun 2007. Peningkatan yang signifikan pada tahun tersebut paling banyak disumbangkan dari pertumbuhan penjualan yogurt yang luar biasa. Namun, data terakhir tahun 2015 menunjukkan peningkatan penjualan produk PTYummy hanya sebesar 6\% dibandingkan tahun 2014. Sampai saat ini PT Yummy belum pernah melakukan penelitian yang berkaitan dengan loyalitas merek dan kepuasan pelanggan. Padahal kepuasan konsumen merupakan faktor kunci untuk kesuksesan sebuah bisnis (Chen et al. 2011). Untuk itu perlu dilakukan penelitian untuk mengetahui seberapa besar tingkat loyalitas merek dan kepuasan pelanggan terhadap yogurt karena menurut Sutanza (2013) loyalitas merek dapat memengaruhi penjualan dan menentukan profitabilitas di masa yang akan datang bagi perusahaan. Di sisi lain, meningkatnya masyarakat kelas menengah dengan pendapatan yang semakin membaik di Indonesia dapat membuat produk susu olahan seperti yogurt menjadi bagian dari gaya hidup (Wiratmaja, 2013). Hal inilah yang menjadi dasar perlunya diketahui pentingnya manfaat mengkonsumsi yogurt, aksessibilitas produk dan akseptabilitas produk untuk memeroleh faktor kunci keberhasilan dalam bisnis yogurt sehingga nantinya dapat dirumuskan strategi dalam meningkatkan loyalitas merek dan kepuasan pelanggan. Permasalahan ini lah yang menjadi daya tarik dan merupakan salah satu dasar pemilihan PT Yummy sebagai objek studi. 
PT Yummy Food Utama (PT Yummy) adalah salah satu perusahaan yang bergerak di bidang industri pengolahan susu, khususnya produk soft fresh cheese, yaitu keju dan yogurt. PT Yummy merupakan salah satu industri pengolahan susu terbesar di Indonesia. Bisnisnya terus berkembang hingga ke seluruh Indonesia. Perusahaan ini telah berdiri 25 tahun dan memiliki berbagai pengalaman dan inovasi-inovasi untuk menciptakan varian-varian baru dari setiap produknya.

Penelitian ini mencoba untuk memahami dan mengidentifikasi faktor-faktor kunci keberhasilan bisnis yogurt di Indonesia, dalam hal ini PT Yummy. Harapannya pelaku bisnis pendatang baru pada industri susu olahan ini dapat mengetahui posisi mereka di dunia agribisnis dan untuk pelaku industri yang sudah berjalan dapat mengikuti strategi bisnis yang telah berhasil dijalankan.

Penelitian ini bertujuan menganalisis faktor-faktor kunci keberhasilan bisnis yogurt PT Yummy dilihat dari pentingnya mengkonsumsi yogurt, aksessibilitas produk dan akseptabilitas produk serta merumuskan strategi untuk meningkatkan brand loyalty dan customer satisfaction PT Yummy. Peneliti membatasi penelitiannya pada cakupan brand loyalty dan customer satisfaction dengan menggunakan analisis deskriptif, kerangka PESTEL dan analisis Porter's Five Forces untuk merumuskan strategi peningkatan brand loyalty dan customer satisfaction pada produk yogurt PT Yummy.

\section{METODE PENELITIAN}

Penelitian ini dilaksanakan di kantor PT Yummy yang beralamat di Jalan Raya Bogor No. 40, Susukan Ciracas, Jakarta Timur. Penelitian ini dilakukan dari bulan Mei hingga bulan Oktober 2016.Penelitian ini dilakukan dengan deskriptif kualitatif dalam bentuk studi kasus pada PT Yummy. Penelitian kualitatif deskriptif adalah metode penelitian yang berlandaskan pada filsafat postpositivisme yang biasanya digunakan untuk meneliti pada kondisi objektif yang alamiah dimana peneliti berperan sebagai instrumen kunci (Sugiyono, 2003). Pada penelitian kualitatif jenis deskripsi tidak diperlukan hipotesa oleh karena tidak dimaksudkan untuk membuktikan sesuatu kebenaran (Subandi, 2011).
Penelitian ini menggambarkan suatu obyek dan masalah secara detail, dan berusaha untuk mengumpulkan berbagai informasi yang ada berdasarkan pedoman pada kuesioner yang diberikan kepada konsumen untuk menganalisis perilaku pentingnya mengkonsumsi yogurt, aksesibilitas produk dan akseptabilitas produk dalam rangka meningkatkan brand loyalty dan customer satisfaction. Metode deskriptif ini bertujuan untuk menggambarkan sifat sesuatu yang sedang berlangsung pada saat penelitian dilakukan dan memeriksa sebab-sebab dari suatu gejala tertentu (Umar, 2003). Selain berdasarkan kuesioner juga dilakukan wawancara mendalam secara langsung untuk dapat mengidentifikasi masalah yang ada serta menganalisis kondisi atau praktik industri pengolahan susu yang sudah ada saat ini.

Data yang digunakan dalam penelitian ini terdiri dari data primer dan data sekunder. Data primer diperoleh dengan melakukan wawancara mendalam dengan berbagai narasumber dari pihak perusahaan serta wawancara terstruktur dengan menggunakan kuesioner untuk konsumen. Metode wawancara dilakukan untuk mengidentifikasi faktor kunci keberhasilan dari perusahaan (Halim et al. 2014). Wawancara mendalam dilakukan langsung secara mendalam sesuai dengan topik penelitian untuk memeroleh data dalam merumuskan strategi peningkatan brand loyalty dan customer satisfaction. Wawancara yang dilakukan adalah wawancara melalui tatap muka dengan informan. Wawancara terstruktur dengan menggunakan kuesioner dilakukan dengan memberikan daftar pertanyaan yang telah dirancang kepada para konsumen. Wawancara terstruktur ini dilakukan untuk memeroleh data mengenai faktor kunci keberhasilan dari bisnis yogurt pada PT Yummy. Data sekunder diperoleh dari dokumen-dokumen perusahaan, berupa profil perusahaan, laporan sebelumnya, serta data penjualan baik yang berasal dari internet dan artikel lainnya.

Penentuan responden dalam penelitian ini menggunakan teknik purposive sampling (dipilih dengan sengaja). Responden dipilih berdasarkan pertimbangan bahwa responden tersebut dianggap ahli dan berkompeten di bidangnya. Responden dalam penelitian ini dibedakan menjadi dua, yaitu responden dari pihak internal perusahaan (direktur dan manajer pemasaran) dan pihak eksternal (konsumen). Penentuan konsumen dilakukan dengan memilih responden yang sehari-harinya mengkonsumsi produk olahan susu. Sebanyak 54 orang responden diperoleh dari 
pelanggan supermarket yang membeli produk olahan susu khususnya yogurt dengan menggunakan teknik purposive sampling.

Metode penelitian yang digunakan adalah dengan pelaksanaan survei kepada pelanggan tentang preferensi dari produk yogurt kemudian dilakukan pemeringkatan berdasar atribut yang dianggap memiliki keuntungan kompetitif bagi pelanggan dan produk yogurt seperti apa yang paling diinginkan oleh pelanggan. Untuk mengetahui faktor-faktor kunci keberhasilan, penelitian ini mengkombinasikan kerangka PESTEL sebagai alat untuk mengidentifikasi faktor makro-lingkungan dan analisis Porter's Five Forces untuk mengetahui lingkungan industri sehingga menunjukkan konsep yang lebih komprehensif. Penelitian ini diharapkan akan menghasilkan faktor-faktor kunci keberhasilan untuk selanjutnya bisa menjadi dasar dari pembuatan strategi bisnis, rencana bisnis, dan rencana pemasaran. Teknik pengolahan dan analisis data terdiri dari uji validitas dan reabilitas, analisis deskriptif dan analisis lingkungan eksternal perusahaan dengan alat bantu analisis, yaitu kerangka PESTEL dan Porter's Five Forces.

\section{Uji Validitas dan Reliabilitas}

Uji validitas dilakukan untuk melihat ketepatan dan kecermatan instrumen dalam melakukan fungsinya sebagai alat ukur (Azwar, 2003). Pengujian validitas diolah menggunakan Software Statistical Package For Social Science (SPSS) Versi 17. Uji reliabilitas dimaksudkan untuk melihat sejauh mana hasil suatu pengukuran instrumen dapat dipercaya.Pengujian reliabilitas yang digunakan pada penelitian ini adalah dengan Alfa Cronbach.

\section{Analisis Deskriptif}

Menurut Nazir (2005) metode analisis deskriptif adalah suatu metode dan meneliti sekelompok manusia, suatu objek, suatu set kondisi, suatu sistem pemikiran ataupun suatu peristiwa pada masa sekarang. Tujuan penelitian deskriptif adalah untuk membuat deskripsi, gambaran, atau lukisan secara sistematis, faktual dan aktual mengenai fakta-fakta, sifat-sifat serta hubungan antar fenomena yang diselidiki (Rahadhika, 2014). Analisis dilakukan dengan metode rataan skor untuk menganalisis perilaku pentingnya mengkonsumsi yogurt, aksesibilitas produk dan akseptabilitas produk terhadap brand loyalty dan customer satisfaction. Metode ini dilakukan dengan teknik rataan skor dengan rentang kriteria penilaian rataan skor pada Tabel 1.

Tabel 1 Indeks penilaian dan kriteria

\begin{tabular}{cl}
\hline Indeks Penilaian & \multicolumn{1}{c}{ Kriteria } \\
\hline $1,00-1,75$ & Sangat Tidak Setuju (STS) \\
$1,76-2,51$ & Tidak Setuju (TS) \\
$2,52-3,27$ & Setuju (S) \\
$3,28-4,00$ & Sangat Setuju (SS) \\
\hline
\end{tabular}

Kerangka PESTEL dan Analisis Porter's Five Forces

Analisis ini digunakan untuk merumuskan strategi dalam meningkatkan brand loyalty dan customer satisfaction. Kusumawardani (2013) menyatakan kerangka PESTEL digunakan sebagai alat untuk mengidentifikasi faktor lingkungan makro yang dikombinasikan dengan analisis Porter's Five Forces untuk mengetahui lingkungan industri.

\section{HASIL}

\section{Uji Validitas dan Reliabilitas}

Uji validitas (variabel pentingnya mengkonsumi yogurt, aksessibilitas produk, dan akseptabilitas produk) menunjukkan bahwa kuesioner yang dipergunakan dalam penelitian ini valid dan diperoleh derajat bebas sebesar 52 sehingga $r$ tabelnya 0,268 . Uji reabilitas menunjukkan bahwa kuesioner yang dipergunakan juga reliabel atau tepat dengan koefisien reliabilitas Alpha-Cronbach sebesar 0,909.

\section{Karakteristik Responden}

Responden pada penelitian ini adalah pelanggan minimarket dan supermarket yang senang mengkonsumsi yogurt. Karakteristik responden diklasifikasikan berdasarkan demografinya, yakni usia, jenis kelamin, status pernikahan, pendidikan terakhir, pekerjaan, pendapatan, moda transportasi ke tempat kerja serta informasi tambahan lain yaitu jenis tempat belanja langganan. Jumlah sampel sebanyak 54 orang. Adapun karakteristik responden berdasarkan informasi demografinya diuraikan pada Tabel 2 . 
Tabel 2. Hasil karakterisitik responden

\begin{tabular}{|c|c|}
\hline Karakteristik & Persentase $(\%)$ \\
\hline \multicolumn{2}{|l|}{ Jenis Kelamin } \\
\hline Pria & 39 \\
\hline Wanita & 61 \\
\hline \multicolumn{2}{|l|}{ Usia (Tahun) } \\
\hline $20-30$ & 70 \\
\hline $31-40$ & 15 \\
\hline$\geq 41$ & 15 \\
\hline \multicolumn{2}{|l|}{ Pendidikan Terakhir } \\
\hline SMA Sederajat & 6 \\
\hline Diploma/ Sarjana & 72 \\
\hline Master/ Doktor & 22 \\
\hline \multicolumn{2}{|l|}{ Status Pernikahan } \\
\hline Menikah & 54 \\
\hline Belum menikah & 46 \\
\hline \multicolumn{2}{|l|}{ Pekerjaan } \\
\hline Pegawai Negeri Sipil & 4 \\
\hline Pegawai BUMN & 22 \\
\hline Pegawai Swasta & 46 \\
\hline Wiraswasta & 13 \\
\hline Lainnya & 15 \\
\hline \multicolumn{2}{|l|}{ Pendapatan Gaji } \\
\hline$<2$ juta & 2 \\
\hline 2,5 juta -10 juta & 64 \\
\hline$>11$ juta & 34 \\
\hline \multicolumn{2}{|c|}{ Pendapatan Lain-Lain } \\
\hline$<1,5$ juta & 26 \\
\hline 2 juta -10 juta & 63 \\
\hline$>11$ juta & 11 \\
\hline \multicolumn{2}{|c|}{ Moda Transportasi ke Tempat Kerja } \\
\hline Kendaraan Umum & 41 \\
\hline Motor & 22 \\
\hline Mobil & 29 \\
\hline Jalan kaki & 8 \\
\hline
\end{tabular}

Hasil karakteristik responden secara keselurahan menunjukkan bahwa pelanggan yang mengkonsumsi yogurt didominasi oleh wanita berusia 20-30 tahun, berstatus pegawai swasta, berpenghasilan antara Rp2,5 juta sampai Rp10 juta dengan pendidikan terakhir diploma/ sarjana yang biasa menggunakan kendaraan umum sebagai alat transportasi untuk menuju ke tempat kerja. Hal ini mengkonfirmasi target market dari PT Yummy berdasarkan hasil wawancara mendalam dengan President Director PT Yummy.

\section{Analisis Deskriptif}

Pentingnya Mengkonsumsi Yogurt

Analisis perilaku responden terhadap pentingnya mengkonsumsi yogurt digunakan untuk mengetahui pengetahuan responden terhadap yogurt dan pentingnya produk yogurt untuk dikonsumsi. Secara umum perilaku responden terhadap pentingnya mengkonsumsi yogurt adalah setuju yang dibuktikan dengan nilai hasil total rataan skor sebesar 2,86 yang berada pada skalasetuju. Gambaran perilaku responden terhadap pentingnya konsumen untuk mengkonsumsi yogurt sudah baik. Artinya konsumen mengetahui dan menyadari pentingnya mengkonsumsi produk yogurt. Akan tetapi, terdapat satuindikator yang masih perlu diperhatikan dalam upaya meningkatkan pengetahuan dan keinginan konsumen untuk mengkonsumsi yogurt yaitu indikator mengenai frekuensi mengkonsumsi yogurt dengan rataan skor terendah sebesar 2,11. Menurut keterangan responden, hal ini dikarenakan produk yogurt masih merupakan salah satu produk olahan susu yang tergolong mewah dan hanya bisa dijangkau oleh masyarakat menengah ke atas mengingat kisaran harga produk yogurt per cup/botol lebih mahal dibandingkan dengan harga susu dalam kemasan. Menurut responden mengkonsumsi yogurt masih dianggap tidak perlu jika dilakukan secara rutin ataupun setiap hari. Untuk itu perlu dilakukan edukasi dan kampanye sehat terhadap produk yogurt untuk menambah wawasan konsumen akan manfaat dan pentingnya mengkonsumsi yogurt.

\section{Aksesibilitas Produk Yogurt}

Analisis perilaku responden terhadap aksesibilitas produk digunakan untuk mengetahui akses konsumen untuk menemukan produk di setiap tempat, seberapa jauh konsumen mengenal produk yogurt PT Yummy dan loyalitas konsumen terhadap produk yogurt PT Yummy. Secara umum perilaku responden terhadap aksesibilitas produk adalah tidak setuju yang dibuktikan dengan nilai hasil total rataan skor sebesar 2,48. Terdapat satu indikator yang sudah baik, yaitu pernyataan yang berkaitan dengan penyebaran distribusi produk dengan rataan skor tertinggi sebesar 2,69. Gambaran aksesibilitas produk yogurt dinilai tidak baik. Ada beberapa indikator yang masih sangat perlu mendapatkan perhatian khusus yaitu brand awareness dan brand loyalty dengan masing-masing rataan skor terendah sebesar 2,13 dan 2,06. Menurut keterangan responden, produk yogurt PT Yummy masih 
belum banyak dikenal oleh masyarakat. Promosi dari produk yogurt PT Yummy masih dianggap kurang baik jika dibandingkan dengan jenis produk yogurt sejenis. Untuk itu kampanye produk yogurt PT Yummy perlu ditingkatkan lagi dengan mengedepankan kelebihan dari produk tersebut. Promosi melalui iklan di televisi, media cetak, media online dan lainnya sangat diperlukan untuk menggeser pandangan masyarakat terhadap produk yogurt. Promosi dapat dilakukan dengan cara yang unik dan berbeda sehingga dapat menarik perhatian para konsumen sehingga dapat meningkatkan brand loyalty para konsumen.

\section{Akseptabilitas Produk}

Analisis akseptabilitas produk digunakan untuk mengetahui seberapa besar produk yogurt PT Yummy dapat diterima oleh responden. Secara umum perilaku responden terhadap akseptabilitas produk adalah setuju yang dibuktikan dengan nilai hasil total rataan skor sebesar 2,56.Gambaran perilaku responden terhadap akseptabilitas produk yogurt PT Yummy sudah baik. Artinya, produk yogurt PT Yummy dapat diterima oleh para konsumen. Akan tetapi, terdapat satu indikatoryang masih perlu diperhatikan dalam upaya memengaruhi responden untuk menerima produk yogurt PT Yummy, yaitu indikator product orientation dengan rataan skor terendah sebesar 2,07. Menurut keterangan responden, hal ini dikarenakan produk yogurt PT Yummy masih belum banyak dikenal sehingga konsumen tidak aware terhadap produk yogurt PT Yummy yang sudah ada di pasaran. Selain itu, responden juga menilai bahwa desain kemasan yang menarik tidak memengaruhi dalam memilih produk yogurt melainkan manfaat, kualitas dan mutu dari produk yogurt yang diutamakan dalam memilih produk. Untuk itu perlu dilakukan pendekatan kepada konsumen dengan membangun komunikasi kepada para pelanggan dengancaramembuat konsumen untuk lebih aktif baik dengan membuka hotline 24 jam via telepon maupun media sosial. Sehingga konsumen dapat lebih leluasa untuk memberikan saran dan kritik yang membangun terkait produk sehingga nantinya diperoleh faktor-faktor apa saja yang dapat memengaruhi pelanggan untuk menerima produk yogurt PT Yummy.

Dari tiga variabel (pentingnya mengkonsumsi yogurt, aksessibilitas produk dan akseptabilitas produk) diperoleh fakta bahwa terdapat enam faktor kunci keberhasilan yang perlu diperhatikan oleh PT
Yummy dalam menentukan strategi usaha, yaitu: frekuensi mengkonsumsi yogurt, pemahaman manfaat mengkonsumsi yogurt, brand awareness, brand loyalty, kualitas produk, dan product orientation.

\section{Analisis PESTEL}

Kerangka PESTEL merupakan salah satu sistem analisis yang dapat digunakan untuk menganalisis lingkungan makro eksternal yang akan memengaruhi semua perusahaan.Menurut Koumparoulis (2013), analisis PEST (Political, Economic, Social, and Technological) menggambarkan kerangka faktor makro-lingkungan yang digunakan dalam komponen scanning lingkungan dari manajemen strategis. Analisis PEST membahas bagaimana perubahan eksternal memengaruhi perusahan dan industri yang kemungkinan akan dijalankan (Gupta, 2013). Hasil analisis PESTEL untuk bisnis yogurt PT Yummy dapat pada Gambar 1 .

Dari hasil analisis menggunakan kerangka PESTEL diketahui bahwa faktor yang paling memengaruhi lingkungan makro eksternal pada PT Yummy adalah faktor sosial (perubahan demografi dan gaya hidup health oriented) dan teknologi (meningkatnya penggunaan media sosial sebagai media promosi dan penggunaan sistem online shop).

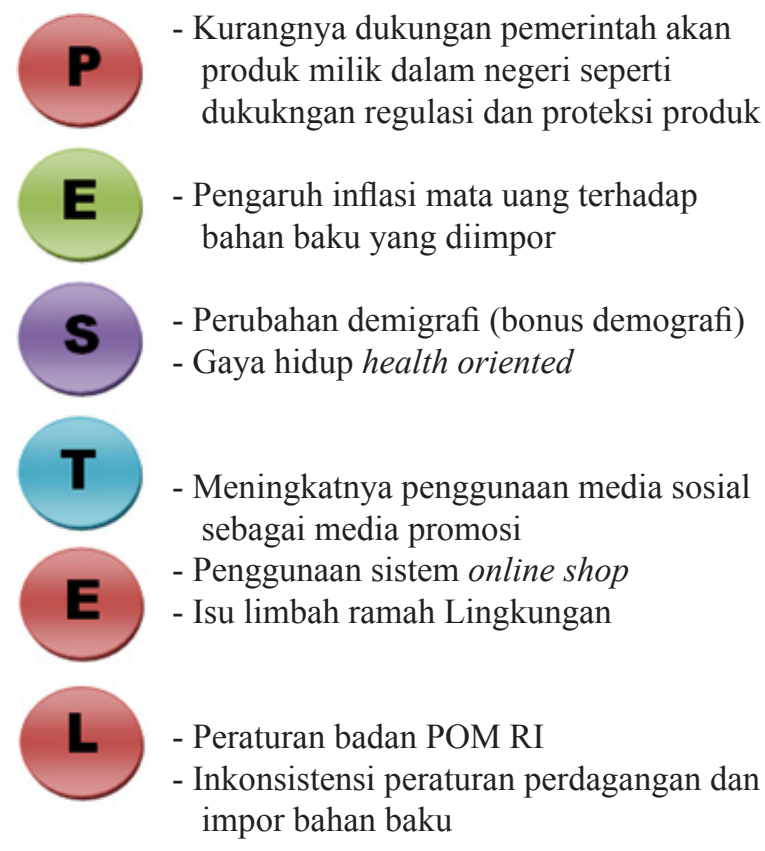

Gambar 1. Hasil analisis kerangka PESTEL 
Perubahan demografi dilihat dari jumlah penduduk Indonesia yang saat ini mencapai 237 juta jiwa (BPS, 2010) yang menjadikan Indonesia sebagai Negara dengan jumlah penduduk terpadat keempat di seluruh dunia. Dari total populasi, sebanyak 49,66 \% adalah wanita dan sebanyak 50,34\% adalah pria. Dilihat dari usia, Indonesia saat ini mengalami bonus demografi dimana jumlah penduduk usia produktif di indonesia adalah sekitar 66\% (156 juta jiwa). Perubahan gaya hidup dan tren yang terjadi di tengah masyarakat saat ini telah memengaruhi pola hidup consumer goods yang mengarah positif di era globalisasi cenderung menunjukkan gaya hidup di masa modern. Perubahan gaya hidup masa modern yang dimaksud antara lain: restoran siap saji (fast food), minuman ringan siap saji, model baju, model rambut, health oriented dan lain sebagainya.Health oriented merupakan salah satu perubahan gaya hidup masyarakat saat ini yang sedang digandrungi oleh masyarakat yang berpendidikan SMA/sederajat ke atas. Penelitian Saufika et al. (2012) menunjukkan bahwa sebagian besar mahasiswa memiliki gaya hidup berorientasi pada hiburan dan kesehatan. Gaya hidup ini dipengaruhi oleh usia, jumlah anggota keluarga, dan kelompok acuan televisi. Sesuai dengan hasil analisis karakteristik responden dimana dominansi konsumen adalah konsumen yang berpendidikan terakhir diploma/sarjana yang telah sadar akan pentingnya kesehatan. Gaya hidup health oriented ini menjadi nilai yang menguntungkan untuk PT Yummy karena sesuai dengan misi perusahaan. Umumnya masyarakat yang terpengaruh akan gaya hidup health oriented adalah masyarakat menengah ke atas dengan pendapatan minimal Rp3 juta per bulan dan dianggap konsen terhadap kualitas dari produk yang dikonsumsi. Hasil penelitian Bloemer dan Kasper (1995) menunjukkan kualitas produk dan pelayanan sangat penting dalam meningkatkan kepuasan dan loyalitas pelanggan.

Berkaitan dengan persaingan pasar global, tidak bisa dipungkiri bahwa kemajuan teknologi dan internet saat ini banyak memengaruhi pola tingkah dan kehidupan masyarakat, diantaranya cara berinteraksi, bersosialisasi, dan berkomunikasi antar sesama. Banyak diantara pelaku usaha yang memanfaatkan kemudahan yang diberikan oleh internet untuk mengkomunikasikan brand, memenuhi pengadaan material, hingga mempromosikan dan menjual produknya kepada konsumen (Nurlaela, 2016). Komunikasi bergerak atau mobile phone communication menjadi trend dan gaya hidup yang semakin digemari di berbagai negara. Begitu juga dengan Negara Indonesia. Pelanggan telepon genggam di Indonesia jauh lebih banyak dibandingkan dengan pelanggan telepon rumah (fixed telephone). Peningkatan jumlah kepemilikan telepon genggamini disebabkan karena semakin murahnya harga telepon genggam dan kepraktisannya yang dapat dibawa kemana saja. Peningkatan yang terjadi dari tahun ke tahun menunjukan fakta bahwa kepemilikan telepon seluler di Indonesia cukup tinggi. Hal tersebut memberikan dampak pada sektor industri telekomunikasi yang semakin berkompetisi. Data menunjukan terjadi peningkatan yang cukup tajam pada total kepemilikan ponsel ke Indonesia (Suryanto, 2012). Kondisi ini dimanfaatkan oleh PT Yummy untuk melakukan promosi di Indonesia melalui media informasi seperti media sosial untuk mengikuti gaya hidup masyarakat yang semakin modern dan dinamis. Menurut Sheng et al. (2012), jumlah penduduk Indonesia yang menggunakan internet diproyeksikan akan mencapai 50 juta orang pada tahun 2014. Berdasarkan data yang dikeluarkan oleh Asosiasi Penyelenggara Jasa Internet Indonesia (APJII), penggunaan teknologi internet di Indonesia mulai tumbuh semenjak tahun 1998. Di tahun 1998 pengguna internet di Indonesia hanya berjumlah 0,5 juta orang. Angka ini terus tumbuh pesat hingga menyentuh angka 63 juta pengguna di tahun 2012 dan diprediksi akan menyentuh angka 139 juta di tahun 2015. Promosi pada media online dibutuhkan untuk mencapai target pemasaran produk PT Yummy yang berdasarkan hasil analisis karakteristik responden konsumennya didominasi oleh wanita aktif berusia 20 30 tahun yang berpendidikan.

\section{Analisis Porter's Five Forces}

Strategi organisasi dalam memahami lingkungan eksternal dapat dikembangkan melalui dua alat analisis, yaitu analisis PESTEL dan analisis Porter's five forces. Analisis Porter's five forces pada PT Yummy dimulai dari ancaman pendatang baru, ancaman produk pengganti, kekuatan tawar-menawar pembeli, kekuatan tawar-menawar pemasok, dan persaingan di antara pesaing yang ada. Persaingan dalam suatu industri tergantung pada gabungan lima kekuatan lingkungan industri. Pengaruh masing-masing kekuatan terhadap bisnis PT Yummy diuraikan pada Gambar 2. 
Dari Gambar 2 dapat dilihat bahwa variabel pentingnya mengkonsumsi yogurt, aksessibilitas produk, dan akseptabilitas produk dipengaruhi oleh kelima kekuatan eksternal industri. Hasil analisis perilaku responden menunjukkan adanya kekuatan tawar-menawar dari pembeli yang memengaruhi keinginan akan pelanggan untuk mengkonsumsi produk yogurt. Hasil dari wawancara terstruktur dengan responden menunjukkan bahwa pelanggan memilih mengkonsumsi yogurt karena rasanya yang enak dan menyehatkan. Ancaman produk pengganti juga memengaruhi perilaku responden. Beberapa responden masih beranggapan bahwa mengkonsumsi susu sapi (baik dalam bentuk susu sapi segar maupun berbentuk susu bubuk) masih lebih baik dan murah dibandingkan mengkonsumsi yogurt. Hal ini dikarenakan ketersediaan produk yogurt yang hanya terdapat di supermarket ataupun minimarket dan tidak terdapat di warung tradisional dimana biasa dijual juga produk susu bubuk.

Hasil kombinasi analisis deskriptif, kerangka PESTEL dan Porter's Five Forces menunjukkan bahwa strategi yang perlu dilakukan oleh PT Yummy untuk meningkatkan brand loyalty dan customer satisfaction dalam menyasarkan target marketyang sesuai dengan kriteria yang diharapkan (berjenis kelamin wanita dengan usia 20-30 tahun, berpendidikan tinggi, dan memiliki pendapatan per bulan antara Rp2,5 juta hingga Rp10 juta) adalah dengan memfokuskan strategi sesuai dengan perkembangan teknologi saat ini yaitu: mengedukasi masyarakat dan menyampaikan manfaat akan pentingnya mengkonsumsi yogurt, meningkatkan popularitas produk melalui media elektronik (via media sosial dan iklan di televisi). Selain itu, PT Yummy juga perlu memfokuskan strategi dengan memertahankan dan menjaga kualitas produk, membangun komunikasi dengan konsumen, dan memerbanyak varian rasa produk.

\section{Implikasi Manajerial}

Beberapa hal yang dapat dijadikan arahan kebijakan bagi manajemen PT Yummy adalah sebagai berikut:

\section{Implikasi teoritis}

Hasil penelitian ini merupakan bukti empiris terhadap teori yang mendasari pentingnya informasi mengenai produk yang dipasarkan yang berorientasi pada kebutuhan konsumen baik ketersediaan produk maupun penerimaan produk oleh konsumen membutuhkan pengelolaan brand loyalty dan customer satisfaction yang optimal sehingga dapat memengaruhi penjualan dan menentukan profitabilitas di masa yang akan datang. Informasi ini sangat penting bagi manajerial untuk menentukan strategi usahanya.

\section{Implikasi praktis}

Temuan dari implikasi teoritis penelitian ini dapat dijadikan sebagai acuan oleh manajemen PT Yummy dalam melakukan kegiatan promosi. PT Yummy dapat memperkuat komunikasi melalui kampanye dan edukasi kepada masyarakat dengan menonjolkan kesehatan dan memertahankan pelanggan. Di samping itu, dengan memperluas sebaran produk. Oleh karena itu, pelanggan akan tetap loyal karena dapat memperoleh produk dimana saja dan kapan saja produk dibutuhkan.

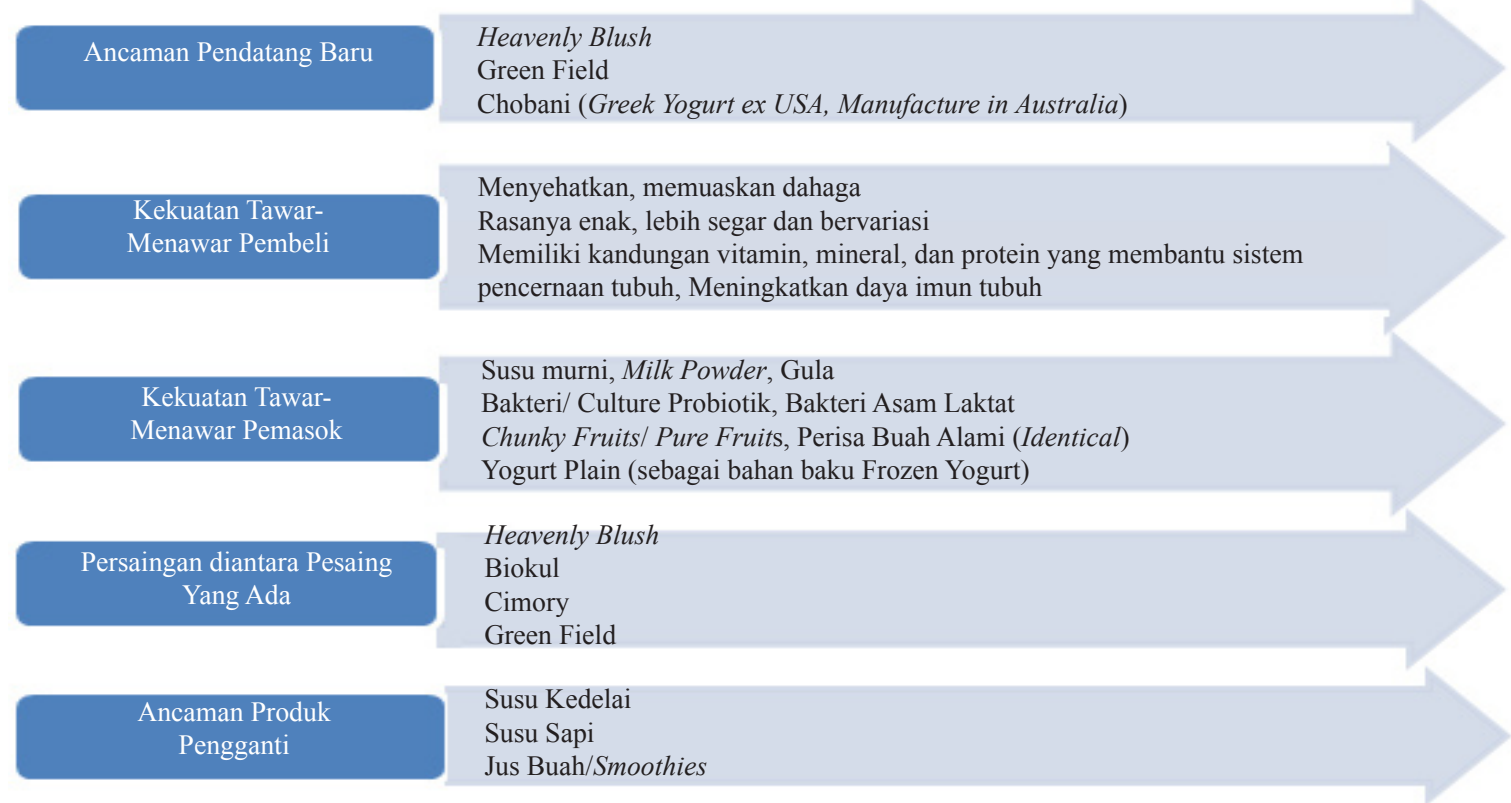

Gambar 2. Hasil analisis Porter's Five Forces 


\section{KESIMPULAN DAN SARAN}

\section{Kesimpulan}

Hasil analisis deskriptif menunjukkan faktor-faktor kunci keberhasilan bisnis yogurt PT Yummy ditinjau dari perilaku pentingnya mengkonsumsi yogurt, aksessibilitas produk dan akseptabilitas produk, yaitu: frekuensi mengkonsumsi yogurt, pemahaman manfaat mengkonsumsi yogurt, brand awareness, brand loyalty, kualitas produk, dan product orientation. Berdasarkan hasil analisis PESTEL faktor kunci keberhasilan dari lingkungan eksternal yang paling memengaruhi adalah kondisi sosial dan teknologi. Sedangkan hasil analisis Porter's Five Forces menunjukkan bahwa faktor kunci keberhasilan yang memengaruhi PT Yummy adalah posisi daya tawar pemasok yang relatif rendah dan adanya ancaman produk pengganti yang tinggi. Dari hasil kombinasi ketiga analisis dapat diformulasikan strategi yang harus dilakukan oleh PT Yummy dalam meningkatkan brand loyalty dan customer satisfaction antara lain: memertahankan dan menjaga kualitas produk, mengedukasi masyarakat dan mendeliver manfaat akan pentingnya mengkonsumsi yogurt, meningkatkan popularitas produk melalui media promosi elektronik (media sosial, iklan di televisi), membangun komunikasi dengan konsumen, membuka hotline gratis 24 jam 7 hari dan memerbanyak varian rasa produk.

\section{Saran}

Penelitian ini menjadi sebuah awalan untuk pengembangan penelitian selanjutnya agar analisis yang ditelaah dapat dilakukan dengan lebih mendalam. Untuk lebih mendapatkan keyakinan akan masalah penelitian ini, dapat dilakukan penelitian lanjutan antara lain melakukan penelitian terhadap pelanggan yang sudah loyal terhadap produk yogurt sehingga diperoleh saran dari pelanggan untuk memeroleh pelanggan baru. Selanjutnya, melakukan penelitian yang difokuskan pada strategi produk untuk meningkatkan product orientation kepada pelanggan. Di samping itu, perlu melakukan penelitian dengan target responden yang berasal dari luar wilayah DKI Jakarta sehingga dapat meningkatkan konsumsi produk yogurt.

\section{DAFTAR PUSTAKA}

Azwar S. 2003. Reliabilitas dan Validitas. Yogyakarta: Pustaka Belajar.

Bloemer JMM, Kasper HDP. 1995. The complex relationship between consumer satisfaction and brand loyalty. Journal of Economic Psychology. 16 (2): 311-329.

[BPS] Badan Pusat Statistik. 2010. Jumlah dan distribusi penduduk. http://sp2010.bps.go.id/ [10 Mar 2016].

Chen YY, Huang HL, Chen YC. 2011. A quality-centred view of customer e-satisfaction and e-loyalty in online shopping. Advances in information Sciences and Service Sciences (AISS) 3(9): 9197.

[DEPPERIN] Departemen Perindustrian. 2009. Roadmap industri susu. http://agro.kemenperin. go.id/. [9 Mei 2016]

Euromonitor International. 2015. Yoghurt and Sour Milk Products in Indonesia. Singapore: Passport.

Gupta A. 2013. Environment and PEST analysis: An approach to external business environment. International Journal of Modern Social Sciences. 2 (1): 34-43.

Halim RE, Azis A, Firmanzah. 2014. Faktor kunci sukses perusahaan kecil dan menengah dalam menghindari kegagalan pada periode lima tahun pertama. Jurnal Pengkajian KUKM 9 (1): 7184.

Herawati T, Priyanto D. 2013. Keragaan kinerja industri pengolahan susu dalam mendukung swasembada susu di Indonesia. Seminar Nasional Teknologi Peternakan dan Veteriner. Bogor: Balai Penelitian Ternak.

Koumparoulis DN. 2013. PEST analysis: The case of e-shop. International Journal of Economy, Management, and Social Sciences 2 (2): 31-36 .

Kusumawardani K. 2013. The key success factors of building daily deals business in Indonesia [tesis]. Bandung: SBM Institut Teknologi Bandung.

Nazir M. 2005. Metode Penelitian. Jakarta: Ghalia Indonesia.

Nurlaela S. 2016. Faktor - faktor penentu online journey dan pengaruhnya terhadap online customer satisfaction dan loyalty [tesis]. Bogor: Institut Pertanian Bogor. 
Rahadhika R. 2014. Pengaruh sertifikasi guru terhadap kesejahteraan dan kinerja guru di Kabupaten Sumedang [tesis]. Bogor: Institut Pertanian Bogor.

Sanny L. 2011. Analisis industri pengolahan susu di Indonesia. Binus Business Review 2 (1): 81-87

Saufika A, Retnaningsih, Alfiasari. 2012. Lifestyle and food habits of college students. Jurnal Ilmu Keluarga dan Konsumen 5(2).

Sheng GY, Priambodo N, Meng-Dar S. 2012. Online shopping behavior in Taiwan and Indonesia [prosiding]. The Asian Conference on Media and Mass Communication 2012. Osaka: International Academic Forum.

Subandi. 2011. Deskripsi kualitatif sebagai satu metode dalam penelitian pertunjukan. Jurnal Harmonia 11 (2): 173-179.

Sudirman. 2009. Analisa strategi pertumbuhan PT Yummy Food Utama dan implikasi terhadap implementasinya [tesis]. Jakarta: Universitas Indonesia.

Sugiyono. 2003. Metode Penelitian Bisnis. Bandung: Pusat Bahasa Depdiknas.
Suryanto B. 2012. Faktor-faktor yang memengaruhi loyalitas konsumen (analisis pengaruh tingkat kepuasan pelanggan, tingkat kualitas jasa, dan tingkat pengetahuan merek terhadap loyalitas konsumen pengguna produk handphone merek NOKIA di Yogyakarta) [tesis]. Yogyakarta: Universitas Atma Jaya Yogyakarta.

Susanto P. 2015. Konsumsi susu masih 11,09 liter per kapita. http://www.kemenperin.go.id/. [11 Apr 2016].

Sutanza B. 2013. Analisis pengaruh brand reputation, brand predictability, brand competence dan brand liking terhadap brand loyalty kendaraan niaga merek Mitsubishi [tesis]. Semarang: Universitas Diponegoro.

Tuthan F. 2014. 80\% kebutuhan susu nasional. http://m. liputan6.com/bisnis/ [ 10 Maret 2016]

Umar H. 2005. Metode Riset Perilaku Konsumen Jasa. Jakarta: Ghalia Indonesia.

Wiratmaja A. 2013. Geliat meningkatnya kelas menengah Indonesia. http://www.rri.co.id/. [10 Mei 2016].

[YFU PT]. 2016. Tentang yummy. http://yummydairy. $\mathrm{com} / \mathrm{html} /$ about/story. 